\title{
Analysis of Low Carbon Energy Application in Ascension Rural Landscape Transformation
}

\author{
Lei Bao, Zhipeng $\mathrm{Wu}$, Xuedong Yang \\ Handan Polytechnic College, Handan, Hebei, China
}

\begin{abstract}
With our country urbanization development, upgrading rural areas gradually attract attention, Hebei government formulated the "Hebei Province Rural Landscape Transformation Promotion Planning and Design Technical Guidelines" in 2013 (hereinafter referred to as the "guidelines"), the use of new energy has been included in the 《guide》, and is one of the 15 special, and use of low carbon energy is also the important content of new energy utilization. The aims of this paper is analyzing the problems existing in current rural planning, summarize the low carbon energy application methods in planning of rural landscape promotion renovation in Hebei Province. As the result puts forward the measures of solar lighting, Flat plate solar photovoltaic power generation, Solar water heater and the suggestions.
\end{abstract}

KEYWORD: low carbon energy; Hebei Province Rural; renovation; solar energy; life cycle

\section{BACKGROUND}

To implement the spirit of the party's conference linked to the 18th National Congress of Communist Party of China and the Third Plenary Session of the eighteen, Comprehensively implement the important instructions of General Secretary Xi Jinping about "China stronger, rural must be strong; Chinese to beauty, rural beauty; Chinese to rich, countryside must be rich". According to the Hebei provincial Party committee and the provincial government requirements, In the scope of Hebei province in 2013, gradually implement rural appearance upgrade planning, so as to improve the quality of life of farmers, change the farmer's lifestyle and improve the rural living environment.

\section{ANALYSIS OF THE CURRENT SITUATION OF RURAL ENERGY RESOURCES IN HEBEI PROVINCE}

Low carbon energy refers to produce less greenhouse gas carbon dioxide in the process of using energy. Usually coal, oil, the natural gas and other fossil energy is called the high carbon energy and traditional energy, because the amount of carbon dioxide per unit of energy produced in far higher than other energy. The corresponding wind energy, solar energy, biomass energy, geothermal energy, nuclear fusion energy, hydrogen energy, tidal energy and other are called low carbon energy, through the investigation of the status, low carbon energy use mainly in solar energy.

Through the survey of current situation in rural areas of Hebei Province, the village energy main focus on electricity, coal, and other traditional energy. The village street lamps were mounted on the poles, all lights are traditional energy generation, some disrepair and need for rectification. Some families use solar water heaters, to take a shower, but there are improper installation problems (Figure $1-2)$.
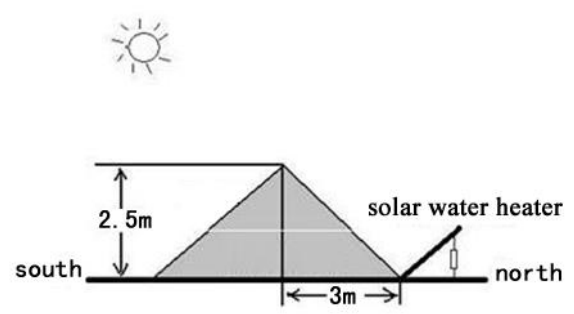

Figure1 Solar water heater improper installation position

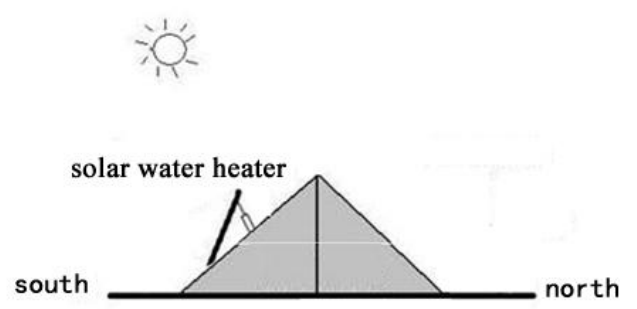

Figure2 Solar water heater installation not combined with changed slope roof 


\section{THE LOW CARBON ENERGY UTILIZATION MEASURES}

In promoting reform plan in the Hebei province rural areas, village construction with a certain scale can adopt solar streetlight project; based on the need of production and life, residential construction should be utilize solar energy and install solar water heaters. Solar design, installation and use, should be consistent with the local residential structure and appearance requirements. When it needs to use the roof erection or wall hanging outside, strictly prohibit destroy the roof, wall, and do a good job of antifreeze, anti lightning, wind, hail and other protective measures. Residence pitched roof solar water heater should be preferred to force or DC loop, should not be used for water storage tank is higher than the natural circulation water heater collector $^{[1]}$. Considering solar water heater attached to the kitchen, bathroom. Residential construction with lower floors in rural areas, less covering with each other, therefore, hot water for life mainly use of solar water heating system as far as possible.

\subsection{Solar lighting}

The installation of solar street lamp, laying no complex line on the road, only need to do a cement base and do a cell pit within $1 \mathrm{~m}$, finally galvanized by the bolts. The construction of solar street lamp is just once investment and benefit keeps long time. Because of its simple circuit, less maintenance costs, and no power consumption, so the solar street lamps own energy-saving environmental protection and economic benefit.

Take actual installation for example, it requires 100 street lamps. The purchase of 100 street lamp and freight is 200000; every street lamp spacing of 30 meters, 15 yuan per meter cable, 3 kilometers street lamp with 3 kilometers cable, which cable needs 45000 yuan; labor costs on box cut should be calculated in accordance with the mounting number, installation cost of each lamp is assumed to be 300 yuan. Total cost is 30000 yuan; in addition to buy Cement Concrete and other equipment, tools, need 10000 yuan; spent a total of 285000 yuan.

If replaced by solar street lamp (Figure3), the cost of each solar street lamp is 2500 yuan, computational installation costs is 300 yuan / lamp, installed 100 solar streetlights and installation cost is 280000 yuan. From the cost, the budgets about purchasing ordinary lamp circuit and solar streetlight have no different. However, solar street lamp without pay for electricity, and the solar battery board with 25 years life span. In addition, because solar street lamps use 12-24V low voltage, it has a lot of advantages just as voltage stability, reliable operation and no security risks.

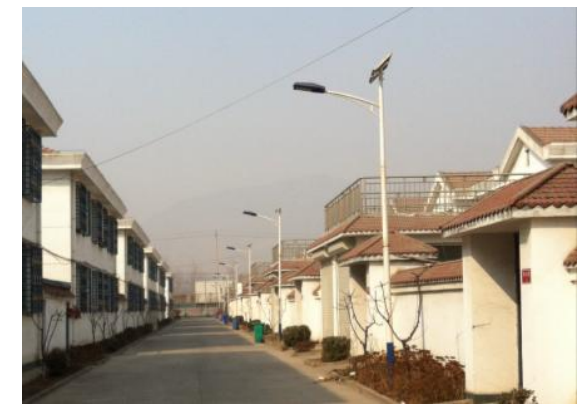

Figure3 Solar street lamp

\subsection{Flat plate solar photovoltaic power generation}

Flat solar photovoltaic power generation is primarily composed of solar modules, solar stent grid or off grid inverter, power distribution boxes and other auxiliary[2]. Take grid connected photovoltaic power generation system as an example(Figure4), through the investigation and analysis, each Watt investment cost of grid connected photovoltaic power generation system includes: PV module 4 yuan + PV stand 1 yuan + PV grid connected inverter 3 yuan + other auxiliary $(4.0+1.0+3.0) \times$ $5 \%=8.4$ yuan, the total cost at least 8.4 yuan $/ \mathrm{W}$. According to the local condition of sunshine, can calculate the amount of generation everyday of the grid connected photovoltaic power system. In hebei province, per $\mathrm{kWp}$ of photovoltaic power system produce daily generation capacity about $3 \mathrm{kWh}$.

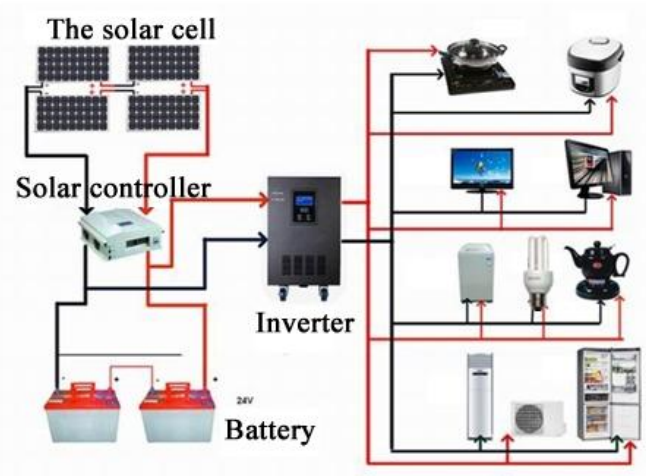

Figure4 Flat plate solar photovoltaic power generation

At present, the life of solar photovoltaic component is about 25 years or more (efficiency is not lower than $80 \%$ ). If calculated according to 20 years, while the life total power is $3 \times 365 \times 20 \times 0.8$ (correction factor) $=17520 \mathrm{kWh}$, and each $\mathrm{kW}$ investment is $8.4 \times 1000=8400$ yuan. Therefore, solar cost of each unit electricity is $8400 / 17520=0.479$ yuan, with little access to the national grid electricity, but if taking the government subsidy into account (now subsidies is for 0.42 yuan each unit), then their electricity cost is 0.479$0.42=0.059$ yuan, therefore, photovoltaic power generation has higher economic benefit.

In addition, when solar photovoltaic produce one degree electricity (KWH), corresponding to save 0.4 $\mathrm{kg}$ of standard coal, so as to reduce emissions 0.272 
kilograms carbon dust, 0.997 kilograms of carbon dioxide, 0.03 kilograms of sulfur dioxide, 0.015 kilograms of nitrogen oxides. Therefore, solar photovoltaic power station can be widely popularized in rural areas, but also can be combined photovoltaic power generation with other energy system, which improves the lives of people and protects the ecological environment in rural areas ${ }^{[3]}$.

\subsection{Solar water heater}

According to the current design of solar water heaters, in Handan area, every square meter lighting area can produce $90 \mathrm{~L}$ hot water. If the hot water heat by electricity, it will consume $1.5 \mathrm{kWh}$ of power. Through calculation, per square meter lighting area of solar water heaters per year can save about $465 \mathrm{kWh}$ power (considering the rainy day, a year is considered as the $85 \%$ sunny day). Per capita usage of living water in rural residents is $70 \mathrm{~L}, 3.5$ persons per household, need 245L living water every day, need to install lighting area of about 3 square meters of solar energy collector. Nearly $1395 \mathrm{kWh}$ electric energy could be saved one year. Calculated in accordance with the 0.5 yuan per degree electricity, about 698 yuan will be saved every year. In addition, through the usage of solar energy water heater, it can enhance and improve the quality of life for rural residents, providing hot water for their lives (Figure $5)$.

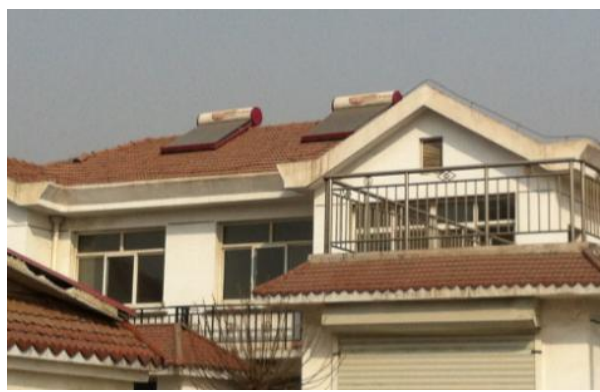

Figure5 Solar water heater

\section{THE RECOMMENDATIONS OF IMPLEMENTATION}

\subsection{Technical supports according to the requirements}

Fully respect the villager's subject status in the rural housing construction and fully reflect the wishes of the villagers, through straightforward way to collect villagers' opinions, to mobilize villagers to actively participate in the whole process of planning and design to improve the rural landscape transformation. Through field investigation, put forward the design objectives and measures to the low carbon energy in rural areas to improve planning applications. Through twinning, introducing the appropriate technical staff and popularizing the construction practices. Guiding people to install new energy technology devices, in order to reduce the high carbon energy ratio.

\subsection{Policy guidance and strengthening propaganda}

Taking a series of the low-carbon energy technologies, will increase the cost. Most of the villagers hope to improve their living environment quality, and also hope to enjoy comfortable with relatively low cost. Many villagers know the usage of low carbon energy sources will inevitably lead to increased costs, but they have no idea about how long can recover the cost. In fact, the cost of low carbon technologies is not high from the angle of low carbon energy life cycle cost analysis. A large number of passive low carbon energy technologies and efficient energy control management reduce building operation energy cost, at the same time, in the realization of comfortable environment benefits, so as to shorten the recovery cycle.

In addition, certain incentive mechanism should be established. Villagers who utilize new energy should be given certain economic benefits, so as to guide the rational consumption of people and a low carbon lifestyle.

\subsection{Implementation of funding, establish mechanism}

Governments at all levels should increase financial input in rural areas of improvement, security operation funds, efforts to form a strong atmosphere of the whole social support. Accelerating the mechanism innovation, strengthen the transformation and upgrading of intrinsic motivation action to establish the rural environment construction, operation, management mechanism. At the same time, the corresponding funds, should fall on the improving quality of life, rather than the "dressing up" beautify the building facade, should maximize the indoor comfort and living level, to guide the rural low-carbon development path.

\section{CONCLUSION}

To sum up, in the rural areas in Hebei province through the transformation of solar lighting, the application and popularization of flat plate solar photovoltaic and solar water heaters and other lowcarbon energy sources, will improve the living environment and quality of farmers. The suggestions in the paper linked to technical support according to the need, policy guidance to strengthen the propaganda, implement funds to set up the mechanism, will be conducive to improve the rural living environment and change villager's lifestyle. Application on low carbon energy in Hebei province 
will realize the unification of economic benefit, environmental benefit and social benefit.

\section{REFERENCES}

[1] Hebei Province Department of housing and urban rural development,rural landscape transformation Hebei province promotion planning and design guidelines,2014 (1)

[2] Zhu Qunzhi, Si Leilei, Jiang Tingyan, economic and environmental benefits, photovoltaic system installation methods of building solar journal, volume thirty-third, first, 2012 (1)

[3] Chinese development report APEC low carbon demonstration town project, 2012 